\title{
EFFECT OF SEAWEED APPLICATION ON THE VEGETATIVE GROWTH OF STRAWBERRY CV. ALBION GROWN UNDER IRAQ ECOLOGICAL CONDITIONS
}

\author{
AL-SHATRI, A. H. N. ${ }^{1}-$ PAKYÜREK, M. ${ }^{1 *}-$ YAVIÇ, A. $^{2}$ \\ ${ }^{1}$ Siirt University Faculty of Agriculture, Department of Horticulture, 56100 Siirt, Turkey \\ ${ }^{2}$ Yüzüncü Yll University Faculty of Agriculture, Department of Horticulture, 65080 Van, Turkey \\ *Corresponding author \\ e-mail: mine.pakyurek@siirt.edu.tr
}

(Received $15^{\text {th }}$ Aug 2019; accepted $14^{\text {th }}$ Nov 2019)

\begin{abstract}
This experiment was established in pots during the vegetative period of 2017, in Kalar Sulaymaniyah, Northern Iraq, to investigate the effect of seaweed extracts (Alga 600) of four concentrations $\left(0,2,4,8\right.$ g. $\left.\mathrm{L}^{-1}\right)$ applied with fertigation system on growth, flowering, yield and quality properties of strawberry cv. Albion. Drip irrigation system was used in this experiment. According to the results in terms of the vegetative growth characteristics, increasing seaweed extract (Alga 600) amounts had significantly different effects on plants with a different number of crowns. The results concerning flower properties show that increasing seaweed extract applications had significant effects on the number of flowers per plant, yielding 16.55-21.77 units/plant. The results in point of fruit properties show that increasing Alga 600 amounts caused a significant increase of 11.81-17.7 units/plant in terms of fruit number, 211.74-329.37 $\mathrm{ml}$ in terms of fruit volume, and an increase of 191.7-295.03 g in terms of yield, compared to the control treatment. The results show that increasing seaweed extract caused a significant increase in fruit quality (TSS/TA ratio from 8.29 to 13.35) compared to the control treatment and increasing seaweed application caused a significant decrease in the TA of the fruit.
\end{abstract}

Keywords: Fragaria $x$ ananassa Duch, organic fertigation, cv. Albion, morphological properties, pomological properties, algae extract

\section{Introduction}

Strawberry (Fragaria x ananassa Duch) is small fruit that planted in a wide range in the world, it belongs to family Rosaceae. Before the relatively modernity development of Fragaria $x$ ananassa, wood strawberries (Fragaria vesca) and Musky strawberries (Fragaria moschata) were cultivated in Europe and Russia for centuries. These species were in generally supplanted by the cultivation of Fragaria $x$ ananassa over the last 250 years. In the early 1700s, inter-planting of Fragaria virginiana (male) with Fragaria chiloensis (female) in France led to the production of hybrid seedlings that bring to be known as Pineapple or Pine strawberry plants, progenitors of the new cultivated strawberry plant (Fragaria $x$ ananassa Duch) (Darrow, 1966). It is a rich source of vitamins and minerals with delicate flavor (Sharma, 2002).

It is one of the most delicious and refreshing temperate fruits of the world. It gives early and very high returns per unit area compared to other fruits because its crop is ready for harvesting within six months after planting (Katiyar et al., 2009). Being a non-climacteric, it matures only on the plant (Cordenunsi et al., 2003). Its fruits are appealing with a distinct, enjoyable and refreshing aroma. It also contains a higher percentage of other components including phenolic and flavonoids (Häkkinen and Törrönen, 2000). Strawberry is a perfect source of Vitamin C (30-100 mg/100 g of fruit) as well as a foliate and photochemical compound such as the Alganic acid. Consuming 
strawberries can reduce the risk of increasing cancer by $50 \%$ due to higher levels of Vitamin $\mathrm{C}$ can increase the flow of blood and oxygen to the muscles by $7 \%$ due to nitrates (Kumar et al., 2013). Strawberry contains 90\% water and 37\% calories, 0.7 grams of protein, $0.5 \mathrm{~g}$ of oil, $10 \mathrm{~g}$ of carbohydrate, $1.3 \mathrm{~g}$ fiber and vitamins, contain vitamin A (0.07 mg), vitamin B1, B2 $(0.3 \mathrm{mg})$, niacin $(28 \mathrm{mg})$ and calcium $(27 \mathrm{mg})$ (Watt et al., 1963).

Strawberry can be cultivated in almost all regions from arctic to tropic regions (Hancock, 1999). Including sub-tropical areas like North of Iraq. Country's weather is favorable for the production of high quality strawberries though it is normally produced in countries having cold weather, particularly in the north. Strawberry cultivation technique is fairly new in North of Iraq whereas cultivation area is increasing bit by bit. Strawberry can be grown during the month of October to April in North of Iraq. A sustainable variety is needed for continuous production from year to year. Screening of strawberry variety is needed for a suitable variety for continuous production and some varietals screening has also done. Today, strawberries are produced in almost every country in the world, most notably, Turkey, America, and Iran. This wide distribution suggests that the strawberry plant is well adapted, and as a genus. However, a lot of individual genotypes or cultivars of strawberries are accurately adapted to local conditions, and so choosing cultivars that are proven to perform well in your specific region is important and key of the work. Strawberry reproduction, fruit quality land yield depends on a lot of factors, for example; weather conditions during the growing stage, the cultivar and all agronomic practices such as fertilization, irrigation or crop protection (Gülsoy and Y1lmaz, 2004).

Cultivated strawberry (Fragaria $x$ ananassa) and wild strawberry (Fragaria virginiana) are plants in the family of Rosaceae. The fruit of the strawberry plant is composed of several tiny fruits that together produce the whole fruit, where every small fruit has one seed called achene. Seaweed extracts are the cheap source of naturally occurring plant development regulators which have better potential as bio stimulants in horticulture. The plant growth regulators available in the seaweed extracts and concentrates is thought to be involved in the enhancing plant growth and yield. Different plant phytohormones and growth regulators available in seaweed extracts are known to promote the yield and yield attributes of crops. Because the extract contains natural plant hormones and deferent natural nutrient material, vitamins, carbohydrates such as Alganic acid, polysaccharide, trace minerals (Panda et al., 2012).

The aim of this study, to investigate the effect of seaweed extract (Alga 600) on the vegetative growth, flowering quantitative and qualitative parameter of yield on strawberry cv. Albion under Iraq ecological conditions.

\section{Literature Review}

Seaweed extract is an organic substance that is concentrated and can be found in liquid or soluble granule form. It is mixed with water and added to seeds, transplant, and plant to fertilize it. Accordingly, as it has been remarked by Aitken and Senn (1965) it can also replace nutrition deficiencies of plant development. This material is an important substance because it is safe to use. It does not have a dangerous side effect on human being, animal and land. In addition to that is reduces land pollution and the rate of soil salt inside the soil (El-Moniem and Abd-Allah, 2008). It is also economical to 
use since it won't cast too much. For the above-mentioned reason, it has been a preferred fertilizer throughout centuries (Temple and Bomke, 1988).

Seaweed extract, in its different types and methods of application, has been a catalyst for plant growth and productivity. As it has been concluded in different studies, seaweed has led to the active development of plants through improving photosynthesis, activating flower, leaves, promoting shoots, leaf minerals, and carbohydrates, vegetative weights. As it has been remarked by Masny et al. (2004) in a study leaves activity improves and photosynthesis will be in better quality when seaweed (Kelpak SL and Goemar BM86®) with three treatments $\left(0,0.5\right.$ and $\left.1 \mathrm{ml} . \mathrm{L}^{-1}\right)$ is sprayed on the leaves of strawberry. It also promotes an increase in the number of flowers in each plant. This experiment is done on strawberry plants cv. Elkat and Salut in 2001-2003. It is also stated it stimulates shoot growth, the area of leaves a long with the chemical components of leave such as carbohydrates and minerals of the leaf. As it is mentioned by Mansour et al. (2006) in an experiment when algae extract added to the sandy soil of thirty Anna apple trees aged 12 years on MM106 rootstock cultivated at $3.5 \times 3.5 \mathrm{~m}$. The effect of the extract is shown in other studies again remarks its positive effect on plant growth. El-Moniem and Abd-Allah (2008) in a study show the positive effect of the extract. The result of spraying green alga cells extract on the grapevine is shown in comparison with other nutrition fertilizers. The use of algae extract at 25 to $100 \%$ had improved on the growth characters, including the leaf area, shoot length and promoted leaves number in each shoot rather than check treatment.

The development and activation of leaves noticed when algae extract concentration was under $50 \%$. But with a concentration above $50 \%$, its effect on increasing percentage $\mathrm{N}, \mathrm{P}$, and $\mathrm{K}$ in the leaves is less than under $50 \%$. Other studies also indicate the positive effect of the extract on plant production and leaf improvement. Taha (2008) in a study exposes the influence of spraying three seaweed extracts (Algren, Soluamine, Mannarine) in two types of Strawberry (Hapil and Kaiser's sampling). It is concluded that spraying cv. Kaiser's sampling with seaweed (Algren) stimulates an increase in the total chlorophyll content and obvious enhance in pollen viability ratio, whereas spraying extracts Soluamine has boosted flower in each plant more than negative controls, as for the cv. Hapil when using Algren extract, there was an increase in dry weight of shoots and leaf area and important superiority of crown diameter. However, spraying extract Soluamine there was an increase in the rate of fresh weight of shoot and dry weight of the root system.

Algae extract increases productivity in strawberry as found by Al-Hermizy (2011) in a study. That deals with the effect of sea algae extract (Alga 600) in two levels (0 and $3 \mathrm{ml} . \mathrm{L}^{-1}$ ) on strawberry growth as far as productivity concerned. The outcome of the study shows that spraying with sea algae extract (Alga 600) caused a significant increase in all vegetative growth characteristics (crown diameter, total leaf area, fresh and dry weight of vegetative growth, number of runner and number of leaflet per plant). Accordingly, Mac et al. (2008) studied the influence of Alga Green (cold process seaweed liquid extract), as foliar fertilization on the plots of mature "Bramley's seedling" apple trees in comparison of other non-applicant trees. It is found that seaweed caused a significant increase in leaf mineral content.

Seaweed can be defined as a fertilizer that makes plant prolific in terms of quantity and quality. As it has been proved in different studies seaweed extract has helped the increase in the rate of fruit weight, size, number. It promotes them to be prolific. As affirmed by Kivijarvi et al. (2002) in a study done on strawberry (Jonsok, Ruukki, and Bounty) with different concentrations of seaweed extract that resulted in the 
improvement of the rate of fruit weight and size, the quantity of yield. There is also a positive outcome of studies done by Al-Hermizy (2011) in search of the impact of seaweed (Alga 600) in two-scale (Zero, and $3 \mathrm{ml} . \mathrm{L}^{-1}$ ) on yield properties of strawberry. The outcome indicated that Spraying with seaweed Alga 600 caused a significant increase in every yield characteristic (fruit weight, size, yield per plant, total yield). Again in other studies like Eshghi et al. (2013), there is a prolific result of using a foliar application of seaweed extracts including Algren at 0,3, 6 and 9 g. $\mathrm{L}^{-1}$, Drin at 0, 0.5, 1 and $2 \mathrm{~g} . \mathrm{L}^{-1}$ focus on quality fruits of strawberry cv. Selva. The results show that the Algren at 9 g.L $\mathrm{L}^{-1}$ focus produces better chlorophyll content.

\section{Material and Methods}

This study was carried out during the vegetation periods of 2016-2017 with pots in open area in Kalar, Sulaymaniyah, North of Iraq located between latitude N 34.62131 ${ }^{\circ}$, longitude E $45.31961^{\circ}$ and on elevation $200 \mathrm{~m}$ above sea level. During the vegetation period, in Kalar, the minimum temperature was $-3^{\circ} \mathrm{C}$; max. the temperature started to increase in the middle of April, more than $35^{\circ} \mathrm{C}$. No field trials have been established to protect plants from low temperatures seen in winter due to continental climatic conditions. When the temperature dropped below zero during the experiment, a plastic sheet was drawn over the plants. Effect of high temperature was seen on strawberry fruit size and weight in our experiment at the beginning of May (it was the last harvest time) as shown in Table 1 (Anonymous, 2017).

Table 1. The weather of Kalar - Sulaymaniyah / Iraq, from January/2017 to June/2017.

\begin{tabular}{c|c|c|c|c|c|c}
\hline Date & $\begin{array}{c}\text { Average } \\
\text { temperature } \\
\text { /month }\end{array}$ & $\begin{array}{c}\text { Maximum } \\
\text { temperature } \\
\text { /month }\end{array}$ & $\begin{array}{c}\text { Minimum } \\
\text { temperature } \\
\text { /month }\end{array}$ & $\begin{array}{c}\text { Average relative } \\
\text { humidity } \\
\text { /month }\end{array}$ & $\begin{array}{c}\text { Maximum } \\
\text { relative humidity } \\
\text { /month }\end{array}$ & $\begin{array}{c}\text { Minimum relative } \\
\text { humidity } \\
\text { /month }\end{array}$ \\
\hline mm/yy & ${ }^{\circ} \mathrm{C}$ & ${ }^{\circ} \mathrm{C}$ & ${ }^{\circ} \mathrm{C}$ & $\%$ & $\%$ & $\%$ \\
\hline Jan-17 & 8.72 & 20.3 & -2.98 & 88.19 & 100 & 0.89 \\
Feb-17 & 12.62 & 25.73 & 0.92 & 73.59 & 100 & 0.9 \\
Mar-17 & 15.7 & 28.22 & 2.47 & 65.59 & 100 & 0.9 \\
Apr-17 & 21.01 & 38.4 & 5.53 & 9.71 & 100 & 0.89 \\
May-17 & 27.49 & 41.91 & 13.66 & 15.27 & 100 & 0.92 \\
Jun-17 & 33.51 & 46.95 & 17.49 & 21.13 & 56.45 & 7.33 \\
\hline
\end{tabular}

\section{Experimental Details}

Albion variety was used as plant material in our experiment. Seedlings were brought at $1^{\text {th }}$ January 2017 from Antalya, Turkey (Figure 1). The experiment was established in pots with capacity $5 \mathrm{~kg}$ in open area on 15 January 2017 in Kalar. Four concentrations of fertigation solutions $\left(0,2,4\right.$ and 8 g.L $\mathrm{L}^{-1}$ ) were prepared from seaweed (Alga 600). The prepared solutions were applied to the plants twice with fertigation. The first application was in the flowering stage (after the formation of first fruiting) and the second application was twenty days later. The seaweed was dissolved in $22^{\circ} \mathrm{C}$ of water for better fixing. Fertigation was applied in the morning. Components of seaweed are shown in Table 2.

\section{Plant Growth Observations and Pomological Properties}

After full flowering (15 $5^{\text {th }}$ February 2017) and two harvesting times (20 $0^{\text {th }}$ March and $12^{\text {th }}$ May 2017) some vegetative growth parameters and pomological properties such as 
single leaf area, total leaf area of per plant, number of leaves per plant, vegetative fresh weight, vegetative dry weight, root dry weight, chlorophyll (total =chlorophyll A + chlorophyll B) content in the plants, strawberry runner properties (daughter plant), strawberry runner properties (stolon), strawberry crown, number of flowers per plant, flower setting percentage, number of fruits of per plant, average fruit weight, average fruit volume, average total fruit volume, yield of per plant, yield per unit area ( $\mathrm{kg} /$ hectare), fruit total soluble solid percentage (TSS \%), fruit total acidity (TA \%), TSS/TA ratio (ripening index) were measured. For measurements of root weight, after second harvest time, the roots of plants were washed to remove the soil particles under tap water very well. Then roots of plants were dried at $70^{\circ} \mathrm{C}$ in the oven.

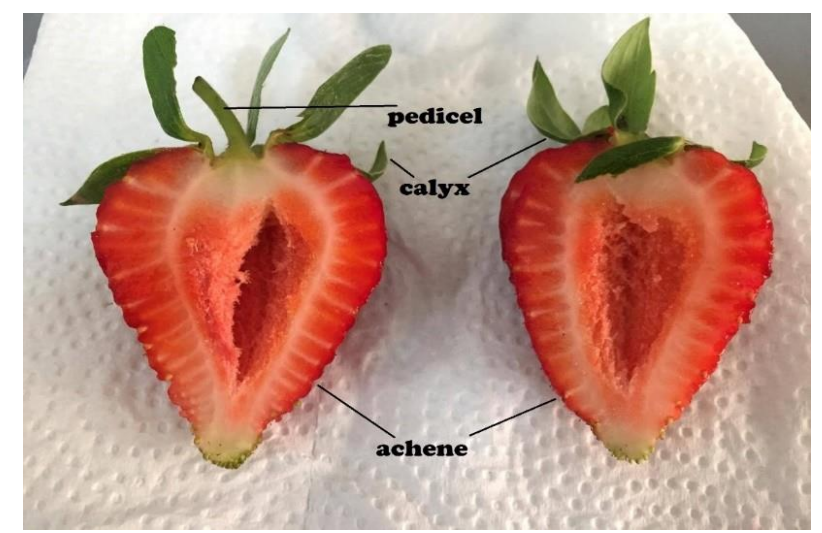

Figure 1. Fruit of Strawberry cv. Albion.

Table 2. Components of seaweed (Alga 600).

\begin{tabular}{c|c|c}
\hline 1 & Nitrogen $\mathrm{N}$ & $0.5-1.0 \%$ \\
2 & Alganic acid & $6-9 \%$ \\
3 & Sulfur $(\mathrm{S})$ & $1.0-1.5 \%$ \\
4 & $6-9 \%$ \\
5 & Phosphorus pentoxide $\left(\mathrm{P}_{2} \mathrm{O}_{5}\right)$ & $0.4-1.6 \%$ \\
6 & Calcium oxide $(\mathrm{CaO})$ & $0.15-0.3 \%$ \\
7 & Iron $(\mathrm{Fe})$ & $0.06 \%$ \\
8 & Magnesium oxide $(\mathrm{MgO})$ & $21-24 \%$ \\
9 & Potassium oxide $\left(\mathrm{K}_{2} \mathrm{O}\right)$ & $4 \%$ \\
10 & Amino acid & $9-11$ \\
11 & PH & $40-50 \%$ \\
\hline
\end{tabular}

\section{Statistical Calculations}

Data were analyzed by the analysis of variance method for randomized plot design. Four treatments $\left(0,2,4\right.$, and 8 g.L $\left.\mathrm{L}^{-1}\right)$, with three replications and each experimental unit, contains nine plants. LSD multiple comparison test was used for determination of the differences between of the means. Significance threshold were set as $\alpha=0.05$ and $\alpha=0.01$. Descriptive statistics, like mean and standard errors, were presented for the investigated features. Statistical calculations of findings are presented under the tables as **: $\mathrm{p}<0.01$, significant at 0,01 level; $*$ p $<0.05$, significant at 0.05 level and NS: not significant. 


\section{Results and Discussion}

\section{Plant Growth Observations and Pomological Properties}

\section{Single Leaf Area Per Plant}

As shown in Table 3, compared to the negative control seaweed (Alga 600) showed an increase in single leaf area per plant. However, it is not a statistically significant result. Measurements gave the maximum value of the single leaf area as $127.88 \mathrm{~cm}^{2}$ in seaweed (Alga 600) in 8 g.L $\mathrm{L}^{-1}$ treatment group. Owing to seaweed (Alga 600) including more vitamins, amino acids, and some trace elements, these results were expected. However, the past studies have demonstrated that seaweed extracts indirectly or directly, effects on the physiological performance of the plants. Previous studies were concluded to be stemming from the content properties of seaweed (Alga 600), which contains auxin and cytokines. Accordingly, cell division and elongation proposed to be affected by the content (El-Yazied et al., 2012; El-Miniawy et al., 2014; Saif Eldeen et al., 2014).

Table 3. The effect of fertigation of seaweed on single leaf area.

\begin{tabular}{c|c}
\hline Name & Single leaf area per plant $\left(\mathbf{c m}^{\mathbf{2}}\right)^{\mathbf{N S}}$ \\
\hline T1 $($ Control $)$ & 102.87 \\
T2 $\left(2 \mathrm{~g} . \mathrm{L}^{-1}\right)$ & 106.52 \\
T3 $\left(4 \mathrm{~g} . \mathrm{L}^{-1}\right)$ & 116.35 \\
T4 $\left(8 \mathrm{~g} . \mathrm{L}^{-1}\right)$ & 127.88 \\
\hline
\end{tabular}

NS: not significantly different.

\section{Total Leaf Area Per Plant}

Data in Table 4 shows the effect of seaweed (Alga 600) on the total leaf area per plant. There is an increase compared with control treatment yet it was not significant, and it shows the fertigation of seaweed (Alga 600) in 8 g.L $\mathrm{L}^{-1}$ give the maximum value of total leaf area per plant is $\left(1464.44 \mathrm{~cm}^{2}\right)$ and lowest value recorded by control treatment $\left(1038.21 \mathrm{~cm}^{2}\right)$. These results are plausibly observed because of the incentive effect of Seaweed (Alga 600) on the single leaf area as previously mentioned.

Table 4. The effect of fertigation of seaweed on total leaf area of per plant.

\begin{tabular}{c|c}
\hline Name & Total leaf area $\left(\mathbf{c m}^{\mathbf{2}}\right)^{\mathbf{N S}}$ \\
\hline T1 $($ Control $)$ & 1038.21 \\
T2 $(2$ g.L. & 1088.56 \\
T3 $\left(4\right.$ g.L $\left.{ }^{-1}\right)$ & 1167.29 \\
T4 $\left(8\right.$ g.L L $\left.^{-1}\right)$ & 1464.44 \\
\hline
\end{tabular}

NS: not significantly different.

\section{The Number of Leaves Per Plant}

The results in Table 5 reveal fertigation levels and their combinations. There is an increasing trend in the number of leaves per plant notwithstanding there is no statistically significant difference among the groups. The highest measurement recorded by fertigation with seaweed (Alga 600) in 8 g.L.- (11.33 unit), and the lowest one recorded by the control group ( 9.48 unit). 
Table 5. The effect of fertigation of seaweed on leaves number of per plant.

\begin{tabular}{c|c}
\hline Name & Number of leaf per plant $^{\text {NS }}$ \\
\hline T1 $($ Control $)$ & 9.48 \\
T2 $(2$ g.L. & 9.74 \\
T3 $\left(4\right.$ g.L - $\left.^{-1}\right)$ & 10.59 \\
T4 $\left(8\right.$ g.L - $\left.^{-1}\right)$ & 11.33 \\
\hline
\end{tabular}

NS: not significantly different.

\section{Vegetative Fresh Weight}

Table 6 shows that the effect of seaweed (Alga 600) on vegetative fresh weight. Despite there is an increasing trend on vegetative fresh weight compared with control, this increase is not significant. The fertigation of seaweed (Alga 600) in 8 g.L.-1 gives the maximum value of vegetative fresh weight $(65.95 \mathrm{~g})$ and the lowest value recorded by control $(53.02 \mathrm{~g})$. These result can be explained by the favorable effects of seaweed for the increase in the parameters such as single leaf area and leaf number per plant (ElMiniawy et al., 2014; Saif Eldeen et al., 2014).

Table 6. The effect of fertigation of seaweed on vegetative fresh weight.

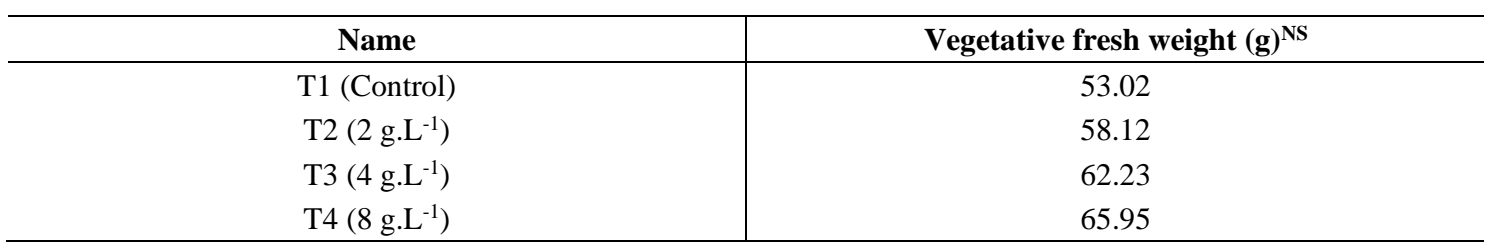

NS: not significantly different.

\section{Vegetative Dry Weight}

As shown in Table 7, the effect of seaweed (Alga 600) on vegetative dry weight, there is a raise compared with control, and it shows the fertigation of seaweed (Alga

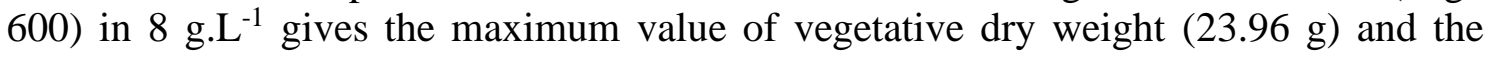
lowest value read by control $(17.74 \mathrm{~g})$. The reason behind this observation might be caused by seaweed (Alga 600) components, as discussed before. Besides, our records revealed that there is an increasing trend for single leaf area, the number of leaves per plant and vegetative fresh weight. Previous studies reported that seaweed extracts lead to the spectacular physiological performance of the plants (El-Yazied et al., 2012; ElMiniawy et al., 2014; Saif Eldeen et al., 2014).

Table 7. The effect of fertigation of seaweed on Vegetative dry weigh.

\begin{tabular}{c|c}
\hline Name & ${\text { Vegetative dry weight }(\mathbf{g})^{\mathbf{N S}}}^{\text {T1 }(\text { Control })}$ \\
T2 $\left(2\right.$ g.L -1 $^{-1}$ & 17.74 \\
T3 $\left(4\right.$ g.L $\left.{ }^{-1}\right)$ & 20.50 \\
T4 $\left(8\right.$ g.L - $\left.^{-1}\right)$ & 21.87 \\
\hline
\end{tabular}

NS: not significantly different. 


\section{Root Dry Weight}

Data in Table 8 shows the effect of seaweed (Alga 600) on root dry weight. The fertigation of seaweed (Alga 600) in $8 \mathrm{~g} . \mathrm{L}^{-1}$ give the maximum value of root dry weight $(12.31 \mathrm{~g})$ and the lowest value recorded by the control group $(8.36 \mathrm{~g})$. Again, we observed an improvement in dry root weight with seaweed (Alga 600) treatment yet it is not significant. Vitamins, minerals and some trace elements might have caused this observation. Our records are compatible with previous studies (Abdel-Mawgoud et al., 2010; Shehata et al., 2011; El-Yazied et al., 2012).

Table 8. The effect of fertigation of seaweed on root dry weight.

\begin{tabular}{c|c}
\hline Name & ${\text { Root dry weight }(\mathbf{g})^{\mathbf{N S}}}^{\text {T1 }(\text { Control })}$ \\
T2 $\left(2\right.$ g.L - $\left.^{-1}\right)$ & 8.36 \\
T3 $\left(4\right.$ g.L - $\left.^{-1}\right)$ & 8.62 \\
T4 $\left(8\right.$ g.L $\left.{ }^{-1}\right)$ & 11.96 \\
\hline
\end{tabular}

NS: not significantly different.

\section{Chlorophyll Content in Plant}

As shown in Table 9, seaweed (Alga 600) augments total chlorophyll content despite the statistically significant difference. The fertigation of seaweed (Alga 600) in 8 g.L.resulted with the maximum value of total chlorophyll content in the leaf (41.09 unit) and the lowest value recorded by the control (38.41 unit). This observation can be grounded by the amino acid content of seaweed. Seaweed treatment eases amino acid accession of the plant which culminates in provoked protein synthesis and this leads to the higher amount of photosynthetic pigment production, the total chlorophyll in the leaves. Previous studies also approve this observation (Thirumaran et al., 2009; Shehata et al., 2011; El-Miniawy et al., 2014; Mohamed, 2015).

Table 9. The effect of seaweed fertigation on total chlorophyll in leaves.

\begin{tabular}{c|c}
\hline Name & Total Chlorophyll in leaf (Unit) \\
\hline T1 $($ Control $)$ & 38.41 \\
T2 $\left(2\right.$ g.L L $\left.^{-1}\right)$ & 38.81 \\
T3 $\left(4\right.$ g.L - $\left.^{-1}\right)$ & 39.72 \\
T4 $\left(8\right.$ g.L L $\left.^{-1}\right)$ & 41.09 \\
\hline
\end{tabular}

NS: not significantly different.

\section{Plant Runner Properties}

Data has shown in Table 10, the effect of seaweed (Alga 600) on number daughter plant and number of stolon that there is an increase compared with control. However, it is not significant, and it pointed that the fertigation of seaweed (Alga 600) in 8 g.L. ${ }^{-1}$ give the maximum value of number daughter plant (4.55 unit) and for number of stolon (7.29 unit) and lowest value recorded by control treatment for daughter plant (3.44 unit) and number of stolons is (5.85 unit). These results suggest that the physiological and biological activity of seaweed extract, containing high levels of auxin and cytokinins, stimulates the cell division in the plant. Another parameter can be $\mathrm{GA}_{3}$ which causes an 
increase of the number of the runners, growth in length of the cell, and elongation of internodes. Our results are coherent with previous papers by Hytönen et al. (2009), Ragab et al. (2010), Abo Sedera et al. (2014) and Mohamed (2015).

Table 10. The effect of fertigation of seaweed on plant runner properties.

\begin{tabular}{|c|c|c|}
\hline Name & Number of runner (daughter plant) ${ }^{\mathrm{NS}}$ & Number of stolon $^{\mathrm{NS}}$ \\
\hline T1 (Control) & 3.44 & 5.85 \\
\hline T2 $\left(2\right.$ g.L.- $\left.{ }^{-1}\right)$ & 3.71 & 6.66 \\
\hline T3 $\left(4\right.$ g. $\left.\mathrm{L}^{-1}\right)$ & 3.70 & 6.70 \\
\hline $\mathrm{T} 4\left(8 \mathrm{~g} . \mathrm{L}^{-1}\right)$ & 4.55 & 7.29 \\
\hline
\end{tabular}

NS: not significantly different.

\section{The Number of Crowns}

Data in Table 11 has showed that the effect of seaweed (Alga 600) on the number of crowns. We observed that there is a significant increase in the number of crowns of treatment groups compared with control. The fertigation of seaweed (Alga 600) in 4 g.L. ${ }^{-1}$ and 8 g.L. ${ }^{-1}$ given rise to the maximum value of the number of crowns (T3=3.64 unit) and (T4=3.5 unit) and the lowest value recorded by control (2.75 unit). These records are thought to be driven by the physiological and biological activity of seaweed extract, which is rich in terms of auxin and cytokinins. Hence, cell division on the plant must be triggered. These results are coherent with studies of Khalid et al. (2013) and Mohamed (2015).

Table 11. The effect of seaweed fertigation on the number of crowns.

\begin{tabular}{c|c}
\hline Name & Number of crown $^{* *}$ \\
\hline T1 $($ Control $)$ & $2.75 \mathrm{~b}$ \\
T2 $\left(2\right.$ g.L $\left.{ }^{-1}\right)$ & $2.719 \mathrm{~b}$ \\
T3 $\left(4\right.$ g.L $\left.{ }^{-1}\right)$ & $3.64 \mathrm{a}$ \\
T4 $\left(8\right.$ g.L - $\left.^{-1}\right)$ & $3.50 \mathrm{a}$ \\
\hline
\end{tabular}

$* *$ : $\mathrm{p}<0.01$, significant at 0.01 level.

\section{Fruit Setting Percentage}

As shown in Table 12, the effect of seaweed (Alga 600) on fruit setting percentage is not significant but an increasing trend is detected $\left(\mathrm{T} 4=8 \mathrm{~g} . \mathrm{L}^{-1}\right)$ compared with control. The fertigation of seaweed (Alga 600) in 8 g.L.-1 culminated in the maximum value of setting percentage $(\mathrm{T} 4=80 \%)$ and the lowest value recorded by control treatment $(\mathrm{T} 1=70 \%)$. These results are consistent with previous studies of Khalid et al. (2013) and Mohamed (2015).

Table 12. The effect of seaweed fertigation on fuit setting percentage.

\begin{tabular}{c|c}
\hline Name & Fruit Setting percentage $^{\text {NS }}$ \\
\hline T1 $($ Control $)$ & $70 \%$ \\
T2 $\left(2\right.$ g.L $\left.{ }^{-1}\right)$ & $74 \%$ \\
T3 $\left(4\right.$ g.L $\left.{ }^{-1}\right)$ & $78 \%$ \\
T4 $\left(8\right.$ g.L $\left.{ }^{-1}\right)$ & $80 \%$ \\
\hline
\end{tabular}

NS: not significantly different. 


\section{The number of fruits per plant}

Records of the number of fruits per plant are shown in Table 13. The significant effect of seaweed (Alga 600) is observed in the number of fruits per plant. Specifically, there was a significant increase in $\mathrm{T} 4$ and $\mathrm{T} 3$ compared with control (T1). The fertigation of seaweed (Alga 600) in 8 g.L $\mathrm{L}^{-1}$ resulted in the maximum value of the number of fruits per plant (T4-17.70 unit) and the lowest value recorded by control treatment (T1-11.81 unit). Increasing the vegetative growth or the number of crowns per plant might be the cause of this finding.

Table 13. The effect of seaweed fertigation on number of fruits per plant.

\begin{tabular}{c|c}
\hline Name & Number of fruits per plant** \\
\hline T1 $($ Control $)$ & $11.81 \mathrm{~b}$ \\
T2 $\left(2\right.$ g.L - $\left.^{-1}\right)$ & $13.40 \mathrm{ab}$ \\
T3 $\left(4\right.$ g.L $\left.{ }^{-1}\right)$ & $17.22 \mathrm{a}$ \\
T4 $\left(8\right.$ g.L $\left.{ }^{-1}\right)$ & $17.70 \mathrm{a}$ \\
\hline
\end{tabular}

**: $\mathrm{p}<0.01$, significant at 0.01 level.

\section{The average weight of the fruit}

The effect of seaweed (Alga 600) is shown in Table 14. Seaweed does not have a significant effect on the average weight of the fruit. On the other hand, we observed an increase in T4 compared with T3 and T2. The maximum value of the average weight of fruit $(\mathrm{g}$ ) was $\mathrm{T} 4=16.85 \mathrm{~g}$ and the lowest value recorded by $\mathrm{T} 3=14.65 \mathrm{~g}$. The seaweed extract improves some vegetative characteristics. It also stimulates production quality and quantity through the enhancement of photosynthetic process. Accordingly, Abdulraheem (2009) has affirmed that seaweed application leads to the improvement in the development of fruit diameter, strength, and length in addition to a better rate of fruit production. In spite of there is no direct correlation between treatment groups, this finding might be caused by increasing the vegetative growth or the number of the crown.

Table 14. The effect of seaweed fertigation on Averae weight of fruit.

\begin{tabular}{|c|c|}
\hline Name & Average weight of fruit $(\mathrm{g})^{\mathrm{NS}}$ \\
\hline T1 (Control) & 15.80 \\
\hline $\mathrm{T} 2\left(2 \mathrm{~g} . \mathrm{L}^{-1}\right)$ & 15.11 \\
\hline T3 $\left(4\right.$ g.L $\left.\mathrm{L}^{-1}\right)$ & 14.65 \\
\hline $\mathrm{T} 4\left(8 \mathrm{~g} \cdot \mathrm{L}^{-1}\right)$ & 16.85 \\
\hline
\end{tabular}

NS: not significantly different.

\section{Average and Total volume of fruit per plant}

In Table 15, data showed the effect of seaweed (Alga 600) on the average volume of fruit $\left(\mathrm{ml}^{3}\right)$. There is no significant effect but there is an increasing trend in T4 compared with other treatments T1 and T2. The fertigation of seaweed (Alga 600) in 8 g.L.-1 gave the maximum value of the average volume of fruit $\left(\mathrm{ml}^{3}\right)\left(\mathrm{T} 4=18.88 \mathrm{ml}^{3}\right)$ and total volume of fruit $\left(\mathrm{ml}^{3}\right) \quad\left(\mathrm{T} 4=329.37 \mathrm{ml}^{3}\right)$ and the lowest value recorded by control treatment. This records can be explained by the fact that seaweed application leads to 
the improvement in the development of fruit diameter, strength, and length in addition to a better rate of fruit production (Abdulraheem, 2009).

Table 15. The effect of seaweed fertigation on average and total volume of fruit.

\begin{tabular}{|c|c|c|}
\hline Name & Average volume of fruit $\left(\mathrm{ml}^{3}\right)^{\mathrm{NS}}$ & Total volume of fruit $\left(\mathrm{ml}^{3}\right)^{*}$ \\
\hline T1 (Control) & 17.50 & $211.74 \mathrm{~b}$ \\
\hline T2 $\left(2\right.$ g.. $\left.\mathrm{L}^{-1}\right)$ & 16.89 & $228.14 b$ \\
\hline T3 $\left(4\right.$ g.L $\left.L^{-1}\right)$ & 16.60 & $285.92 \mathrm{ab}$ \\
\hline T4 $(8$ g.L.-1) & 18.88 & $329.37 \mathrm{a}$ \\
\hline
\end{tabular}

NS: not significantly different, *: $\mathrm{p}<0.05$, significant at 0.05 level.

\section{Plant yield and yield per area unit}

The influence of seaweed (Alga 600) on yield per plant (g) and per hectare (kg/ha) are shown in Table 16. There is a significant increase in T4 compared with control (T1) and T2. The fertigation with seaweed (Alga 600) in and 8 g.L. $\mathrm{L}^{-1}$ resulted in the maximum value of yield per plant (g) T4-295.03 g and per hectare T4-3278.18 kg/ha. The lowest value belongs to the negative control. This results can be explained as seaweed extract improves some vegetative characteristics. It also stimulates the quality and quantity of production through the augmentation of the photosynthetic process. Accordingly, Abdulraheem (2009) has affirmed that seaweed application leads to the improvement in the development of fruit diameter, strength, and length in addition to a better rate of fruit production. This increase leads to improved vegetative growth or number of the crowns.

Table 16. The effect of seaweed fertigation on yield per plant and yield per hectare.

\begin{tabular}{c|c|c}
\hline Name & Yield per plant $(\mathbf{g})^{*}$ & ${\text { Yield per hectare }(\mathbf{k g} / \text { hectare })^{*}}^{*}$ \\
\hline T1 $($ Control $)$ & $191.70 \mathrm{~b}$ & $2130.04 \mathrm{~b}$ \\
T2 $\left(2\right.$ g.L $\left.\mathrm{L}^{-1}\right)$ & $204.11 \mathrm{~b}$ & $2267.90 \mathrm{~b}$ \\
T3 $\left(4\right.$ g.L $\left.{ }^{-1}\right)$ & $254.11 \mathrm{ab}$ & $2823.45 \mathrm{ab}$ \\
T4 $\left(8\right.$ g.L $\left.\mathrm{L}^{-1}\right)$ & $295.03 \mathrm{a}$ & $3278.18 \mathrm{a}$ \\
\hline
\end{tabular}

*: $\mathrm{p}<0.05$, significant at 0.05 level.

\section{Total soluble solid (TSS)}

According to the findings in Table 17, the effect of seaweed (Alga 600) on total soluble solid (TSS) that there is an increase compared with control. However, it was not significant and it has shown the fertigation of seaweed (Alga 600) in 8 g.L. $\mathrm{L}^{-1}$ resulted in the maximum value of total soluble solid (TSS) (7.46 unit) and lowest value recorded by control (6.85 unit). These results are compatible with reports from El-Moniem and Abd-Allah (2008) and Taha (2008).

\section{Total acidity $(T A)$}

In Table 18 the effect of seaweed (Alga 600) on total acidity (TA), there are significant differences among the treatment groups. Increasing of levels of seaweed extract (Alga 600) decreases the TA, control treatment has significantly different than $\mathrm{T} 2$ and higher than T4 but it is not significant, and it showed the maximum value in 
control treatment and lowest value recorded by fertigation of seaweed (Alga 600) in 2 g.L. $\mathrm{L}^{-1}$, because while TSS increase, the TA decrease.

Table 17. The effect of seaweed fertigation on total soluble solid.

\begin{tabular}{c|c}
\hline Name & Total soluble solid (TSS) $^{\text {NS }}$ \\
\hline T1 $($ Control $)$ & 6.85 \\
T2 $(2$ g.L. & 7.39 \\
T3 $\left(4\right.$ g.L L $\left.^{-1}\right)$ & 7.05 \\
T4 $\left(8\right.$ g.L L $\left.^{-1}\right)$ & 7.46 \\
\hline
\end{tabular}

NS: not significantly different.

Table 18. The effect of seaweed fertigation on Total acidity.

\begin{tabular}{c|c}
\hline Name & Total acidity ${ }^{*}$ (TA) \\
\hline T1 (Control) & $0.88 \mathrm{a}$ \\
T2 $\left(2\right.$ g.L - $\left.^{-1}\right)$ & $0.69 \mathrm{~b}$ \\
T3 $\left(4\right.$ g.L - $\left.^{-1}\right)$ & $0.74 \mathrm{ab}$ \\
T4 $\left(8\right.$ g.L L $\left.^{-1}\right)$ & $0.80 \mathrm{ab}$ \\
\hline
\end{tabular}

*: $\mathrm{p}<0.05$, significant at 0.05 level.

\section{TSS/TA ratio (ripening index)}

The findings have shown in Table 19, the effect of seaweed (Alga 600) on TSS/TA ratio in $\mathrm{T} 4$ and $\mathrm{T} 2$ significantly increased compared with control. It showed the fertigation of seaweed (Alga 600) in 8 g.L $\mathrm{L}^{-1}$ gave the maximum value of TSS/TA ratio (13.35 unit) and the lowest value recorded by control treatment ( 8.29 unit). These results are coherent with that information by El-Moniem and Abd-Allah (2008) and Taha (2008).

Table 19. The effect of seaweed fertigation on TSS/TA ratio.

\begin{tabular}{c|c}
\hline Name & TSS/TA ratio $^{* *}$ \\
\hline T1 (Control) & $8.29 \mathrm{~b}$ \\
T2 $(2$ g.L.-1 $)$ & $13.11 \mathrm{a}$ \\
T3 $\left(4\right.$ g.L $\left.{ }^{-1}\right)$ & $11.81 \mathrm{ab}$ \\
T4 $\left(8\right.$ g.L - $\left.^{-1}\right)$ & $13.35 \mathrm{a}$ \\
\hline
\end{tabular}

$* *: \mathrm{p}<0.01$, significant at 0.01 level.

\section{Conclusion}

According to the results of our study the effect of seaweed (Alga 600) on the flowering, vegetative growth and fruiting of strawberry cv. Albion, the following conclusion can be drawn. The seaweed extract at 2 g.L $\mathrm{L}^{-1}$ is less effective on strawberry vegetative properties, flowering and yield properties and chemical characteristics of fruit than other treatment. The seaweed extract (Alga 600) at 4 g.L. $\mathrm{L}^{-1}$ is more effective than $2 \mathrm{~g} . \mathrm{L}^{-1}$ and it has a significant effect on the number of the crowns, number of flowers, number of the fruits at 0.01 level, and total volume of the fruit, yield per plant, yield per hectare, TA and TSS/TA ratio at 0.05 level. The seaweed extract at a higher 
concentration ( 8 g. $\left.\mathrm{L}^{-1}\right)$ has the more effective to increase the vegetative growth, flowering and yield properties. Organic fertigation (Alga 600) has a significant effect on the number of the crown, number of flowers, number of the fruit at 0.01 level, and total volume of fruit, yield per plant, yield per hectare, TA and TSS/TA ratio.

Seaweed fertilizers are an important alternative organic fertilizing to increase yield and to achieve a better quality product. The use of seaweed as support for fertilization in production increases the yield and quality while ensuring the sustainability of the soil due to its ecological nature. Strawberry, with high economic returns; rich in taste, aroma and antioxidant substances and no marketing problems, is a fruit. Strawberry cultivation is not common in Iraq yet. In this sense, the result of our study is a guide for those who want to cultivate strawberry in Iraq. In conclusion, as the amount of seaweed extract applied increased, vegetative growth rate and flowering rate increased in our experiment. For this reason, in particular, we believe that the application of doses above $8 \mathrm{~g} . \mathrm{L}^{-1}$ will significantly increase the productivity and quality of yield.

Acknowledgements. This article is produced from the MSc Thesis belongs to A.H.N. AL-SHATRI and the thesis has been funded with the project (2017-SIUÜFEB-90) by Scientific Research Projects Council, Siirt University.

\section{REFERENCES}

[1] Abdel-Mawgoud, A. M. R., Tantawy, A. S., Hafez, M. M., Habib, H. A. M. (2010): Seaweed extract improves growth, yield and quality of different watermelon hybrids. - Res. J. Agric. \& Biol. Sci. 6(2): 161-186.

[2] Abdulraheem, S. M. (2009): Effect of nitrogen fertilizer and seaweed extracts on vegetative growth and yield of cucumber. - Diyala Agric. Sci. J. 1: 134-145.

[3] Abo Sedera, F. A., Bader, L. A., Abd El-Latif, A. A., Rezk, S. M. (2014): Effect of mineral N, P plus P Bio-fertilizer levels and foliar spray with calcium and seaweed extract on strawberry productivity. - J. Biol. Chem. Environ. Sci. 9(3): 343-366.

[4] Aitken, J. B., Senn, T. L. (1965): Seaweed products as a fertilizer and soil conditioner for horticultural crops. - Botanica Marina 8(1): 144-147.

[5] Al-Hermizy, S. M. M. (2011): Study the effect of Cyanobacteria Inoculation and Spraying of Sea Alga (Alga 600) in growth and yield and chemical properties of strawberry plants (Fragaria x ananass Duch). - Journal of Tikrit Univ. for Agric. Sci. 11(3): 40-50.

[6] Anonymous (2017): Statistical data. - Agrometeorology Directorate, Sulaymaniyah / Iraq.

[7] Cordenunsi, B. R., Nascimento, J. D., Lajolo, F. M. (2003): Physico-chemical changes related to quality of five strawberry fruit cultivars during cool-storage. Food Chemistry 83(2): 167-173.

[8] Darrow, G. (1966): The Strawberry: history, breeding and physiology. - Holt, Rinehart and Winston, New York, Chicago, 447 p.

[9] El-Miniawy, S. M., Ragab, M. E., Youssef, S. M., Metwally, A. A. (2014): Influence of foliar spraying of seaweed extract on growth, yield and quality of strawberry plants. - Journal of Applied Sciences Research 10: 88-94. 
[10] El-Moniem, E. A. A., Abd-Allah, A. S. E. (2008): Effect of green Alga cells extract as foliar spray on vegetative growth, yield and berries quality of superior grapevines. - J. Amer. Eur. Agric. and Environ. Sci. 4(4): 427-33.

[11] El-Yazied, A. A., El-Gizawy, A. M., Ragab, M. I., Hamed, E. (2012): Effect of seaweed extract and compost treatments on growth, yield and quality of snap bean. - Journal of American Science 8(6): 1-20.

[12] Eshghi, S., Zare, M., Jamali, B., Gharaghani, A., Farahi, M. H. (2013): Vegetative and Reproductive Parameters of Selva Strawberry as Influenced by Algren, Drin and Green Hum Foliar Application. - Agricultural Communications 1(1): 27-32.

[13] Gülsoy, E., Y1lmaz, H. (2004): The effects on adaptation of some strawberry cultivars grown under different tunnels in Van ecological conditions. - YYU. J. Inst. Natural Applied Sci. 9(1): 50-57.

[14] Hancock, J. F. (1999): Strawberries. - CABI Publishing, Wallingford, Oxon 0X10 8DE, UK. 237 p.

[15] Häkkinen, S. H., Törrönen, A. R. (2000): Content of flavonols and selected phenolic acids in strawberries and Vaccinium species: influence of cultivar, cultivation site and technique. - Food research international 33(6): 517-524.

[16] Hytönen, T., Elomaa, P., Moritz, T., Junttila, O. (2009): Gibberellin mediates daylength-controlled differentiation of vegetative meristems in strawberry (Fragaria $\times$ ananassa Duch). - BMC Plant Biology 9(1): 18.

[17] Katiyar, P. N., Singh, J. P., Singh, P. C. (2009): Effect of mulching on plant growth, yield and quality of strawberry under agro-climatic conditions of Central Uttar Pradesh. - International Journal of Agricultural Sciences 5(1): 85-86.

[18] Khalid, S., Qureshi, K. M., Hafiz, I. A., Khan, K. S., Qureshi, U. S. (2013): Effect of organic amendments on vegetative growth, fruit and yield quality of strawberry. - Pakistan Journal of Agricultural Research 26(2).

[19] Kivijärvi, P., Prokkola, S., Aflatuni, A., Parikka, P., Tuovinen, T. (2002): Cultivation techniques for organic strawberry production in Finland. Proceedings of the fourth international strawberry symposium: volume 2/ed. International Society for Horticultural Science.

[20] Kumar, R., Saravanan, S., Bakshi, P., Sharma, R. M. (2013): Influence of Gibberellic Acid and Blossom Removal on Fruit Quality of Strawberry (Fragaria $x$ ananassa Duch.) CV. Belrubi. Vegetos. - An International Journal of Plant Research 26(1): 107-110.

[21] Macant-Saoir, S., Archer, J. (2008): The effect of Alga green 200 (cold-process seaweed liquid extract) on the mineral content of 'Bramley's Seedling' apple leaves and fruit. - VI International Symposium on Mineral Nutrition of Fruit Crops 868: 301-306.

[22] Mae, H., Ooi, J., Takahashi, S., Tomonari, A., Tsukada, N., Konumai, T. (2008): Early renal injury after myeloablative cord blood transplantation in adults. - Leuk Lymphoma 49: 538-42.

[23] Mansour, A. E., Cimpoies, G., Ahmed, F. F. (2006): Application of Alga extract and boric acid for obtaining higher yield and better fruit quality of Anna apple. Stiinta agricola (Republic of Moldova) 2: 14-20.

[24] Masny, A., Basak, A., Zurawicz, E. (2004): Effects of foliar applications of Kelpak SL and Goëmar BM 86® preparations on yield and fruit quality in two strawberry cultivars. - Journal of fruit and ornamental plant research (12): 23-27. 
[25] Mohamed, M. (2015): Effect of some growth stimulants on production and quality of strawberry transplants. - Annals of Agric. Sci. Moshtohor 53(4): 693-708. ISSN 1110-0419.

[26] Panda, D., Pramanik, K. B., Naya, R. (2012): Use of sea weed extracts as plant growth regulators for sustainable agriculture. - Int. J. Biores. Stress Manage. 3(3): 404-411.

[27] Ragab, M. E., Omran, A. E., Youssef, S. M., Sabt, W. M. (2010): Effect of some application and agricultural practices on runner formation and transplant production in strawberry nurseries. - J. Biol. Chem. Environ. Sci. 5(4): 247-261.

[28] Saif Eldeen, U. M., Shokr, M. M., Shotoury, R. S. (2014): Effect of foliar spray with seaweeds extract and chitozan on earliness and productivity of globe artichoke. - Journal of Plant protection, Mansoura Univ. 5(7): 1197-1207.

[29] Sharma, R. R. (2002): Growing strawberry. - Int. Book Distributing Co., India 1: 01-02.

[30] Shehata, S. M., Abdel-Azim, H. S., El-Yazied, A. A., El-Gizawy, A. M. (2011): Effect of foliar spraying with amino acids and seaweed extract on growth chemical constitutes, yield and its quality of celeriac. - Plant. Euro. J. Sci. Res. 58(2): 257-265.

[31] Taha, S. M. (2008): Effect of foliar spray of gibberellic acid, Cycocel and three of seaweed extract in some characters of vegetative growth, flower and yield components characteristics of two varieties of strawberry (Fragaria $\times$ ananassa Duch.). - PhD Thesis. Dept of Hort. and Forest. College of Agric. Uni. Salah Eldin - Erbil.

[32] Temple, W. D., Bomke, A. A. (1988): Effects of kelp (Macrocystis integrifolia) on soil chemical properties and crop responses. - Plant Soil 105: 213-222.

[33] Thirumaran, G., Arumugam, M., Arumugam, R., Anantharaman, P. (2009): Effect of seaweed liquid fertilizer on growth and pigment concentration of Abelmoschus esculentus (1) medikus. - American-Eurasian Journal of Agronomy 2(2): 57-66.

[34] Watt, B. K., Merrill, A. L., Pecot, R. K. (1963): Composition of Foods: Raws, Processed, Prepared. - Agriculture Handbook No: 8. Washington, DC. US Department of Agriculture. 